\title{
(0.2) Scoping Experiments; (02.3) Long-Term Corrosion Testing and Properties Evaluation of Candidate Waste Package Basket Materials
}

\author{
Richard A. Van Konynenburg
}

December 20, 1996

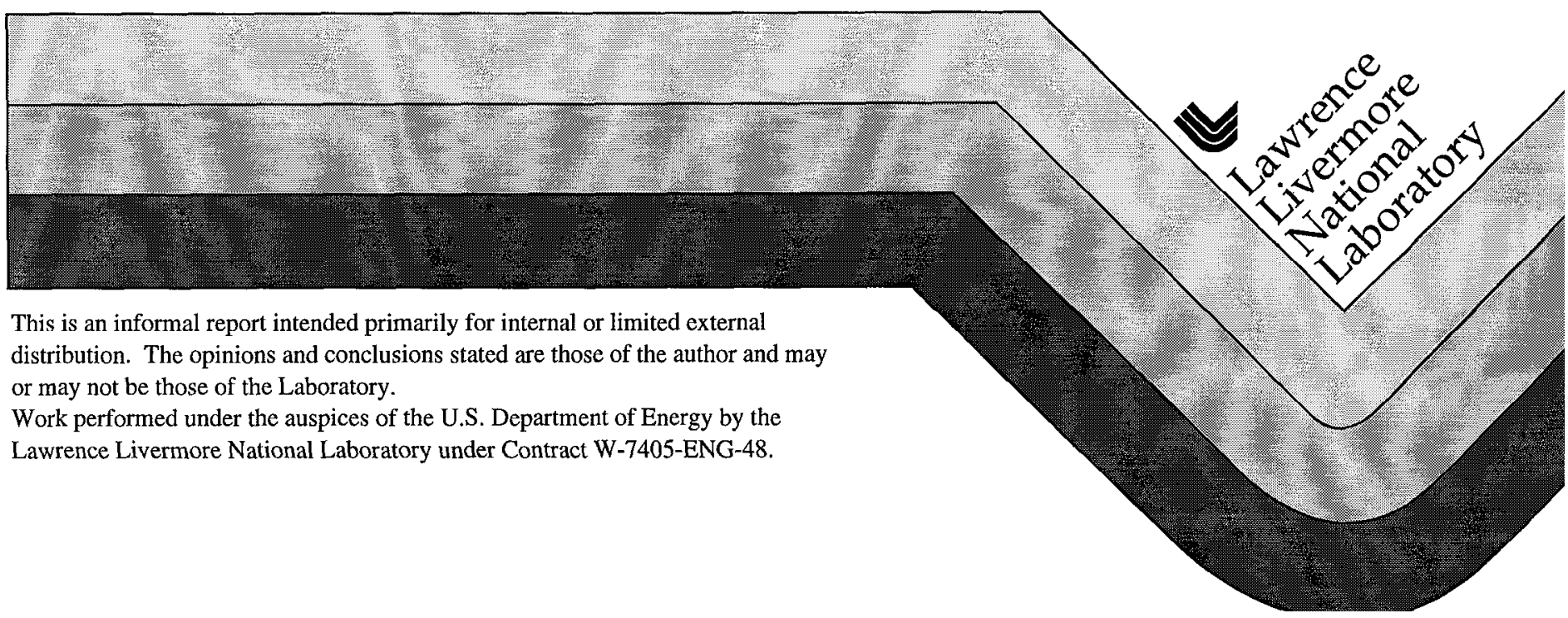




\section{DISCLAIMER}

This document was prepared as an account of work sponsored by an agency of the United States Government. Neither the United States Government nor the University of California nor any of their employees, makes any warranty, express or implied, or assumes any legal liability or responsibility for the accuracy, completeness, or usefulness of any information, apparatus, product, or process disclosed, or represents that its use would not infringe privately owned rights. Reference herein to any specific commercial product, process, or service by trade name, trademark, manufacturer, or otherwise, does not necessarily constitute or imply its endorsement, recommendation, or favoring by the United States Government or the University of California. The views and opinions of authors expressed herein do not necessarily state or reflect those of the United States Government or the University of California, and shall not be used for advertising or product endorsement purposes.

This report has been reproduced directly from the best available copy.

Available to DOE and DOE contractors from the Office of Scientific and Technical Information

P.O. Box 62, Oak Ridge, TN 37831

Prices available from (423) 576-8401

Available to the public from the

National Technical Information Service

U.S. Department of Commerce

5285 Port Royal Rd.,

Springfield, VA 22161 
University of California

II Lawrence Livermore

National Laboratory

YUCCA MOUNTAIN PROJECT

Activity Plan
No.:

Revision: $\quad 0$

Change Notice:

AP-CM-02.2/02.3-0-1

Page:

AUTHOR:

(02.2) Scoping Experiments; (02.3) Long-Term Corrosion Testing and Properties Evaluation of Candidate Waste Package Basket Materials
Richard A. Van Konynenburg

Training Required: Yes $\square$ No $\square$

Comments:

N/A

\section{REVISION HISTORY}

Rev. No. CN No. Effective Date: Description of Revision/CN

0

0
$11 / 22 / 96$

AP-CM-02.2/02.3-0-1 12/20/96
Original issue.

Deleted reference to PACS. Affects Title Page and page 5 of 8.

APPROVALS:

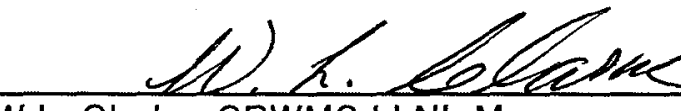

W.L. Clarke, CRWMS LLNL Manager

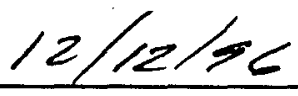

Date

1

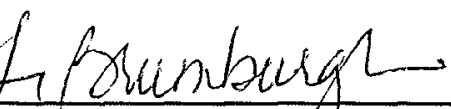
fer. $\frac{12 / 10 / 46}{\text { Date }}$ R.E. Monks, M\&O LLNL Qubity Assuran\&e Manager

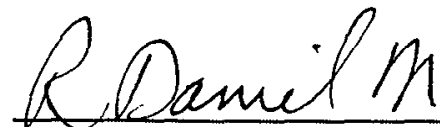


1.0 INTRODUCTION.

1.1 Site Characterization Plan and Work Breakdown Structure Numbers.....1

1.2 Scientific Investigation Plan .........................................

1.3 Information Requirements .........................................

1.4 Activity Identities, Objectives and Scope ..........................

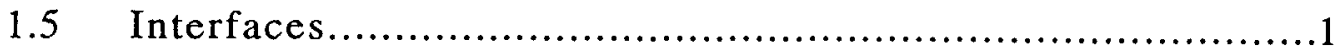

1.6 Assignments and Responsibilities ...................................2

$2.0 \quad$ ACTIVITY DESCRIPTIONS ............................................

2.1 Sub-tasks, Technical Approaches, and Methods.............................2

2.2 Materials ...........................................................

2.3 Environments.....................................................

2.4 Parameters to be Measured ........................................ 3

2.5 Prerequisites and Sequence of Operations ..............................3

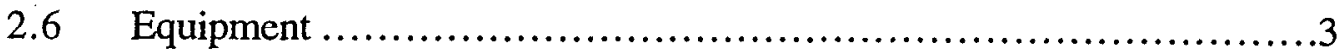

$2.7 \quad$ Precision and Accuracy ............................................

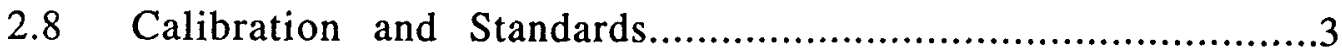

2.9 Sources of Uncertainty ..........................................

2.10 Data Recording and Analysis ........................................4

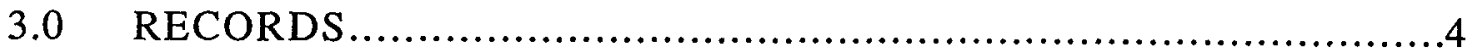

4.0 QUALITY ASSURANCE PROGRAM........................................4

5.0 READINESS AND TECHNICAL REVIEWS AND VERIFICATION ..........4

6.0 HOLD POINTS AND DECISION POINTS .................................4

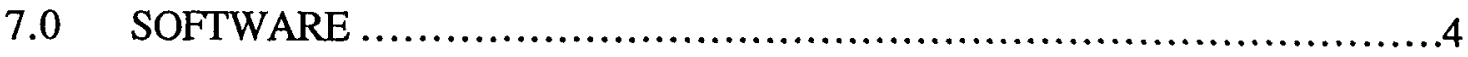

8.0 TECHNICAL IMPLEMENTING PROCEDURES ..........................5

9.0 QUALIFICATIONS AND TRAINING ..................................

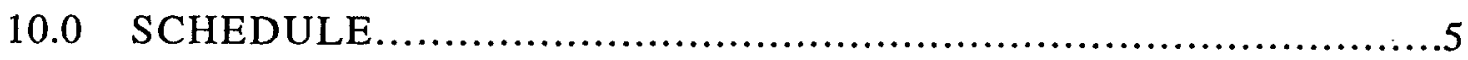

11.0 PROCUREMENTS AND SUBCONTRACTORS ...........................5

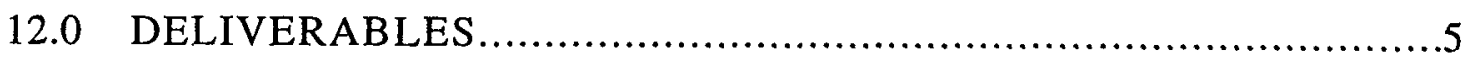

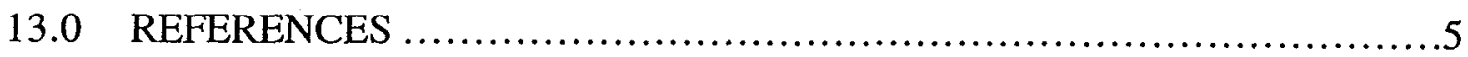




\section{ACTIVITY PLAN}

\section{AP-CM-02.2: Scoping Experiments}

and

\section{AP-CM-02.3: Long-Term Corrosion Testing and Properties Evaluation of} Candidate Waste Package Basket Materials

YMP WBS Element 1.2.2.5.2

Waste Package Basket Materials

Lawrence Livermore National Laboratory 


\subsection{INTRODUCTION}

1.1 Site Characterization Plan and Work Breakdown Structure Numbers

The work described in this activity plan addresses Information Need 2.7.3 of the Yucca Mountain Site Characterization Plan (1), which reads "Determination that the design criteria in 10CFR60.130 through 60.133 and any appropriate additional design objectives pertaining to criticality control have been met." This work falls under section WBS 1.2.2.5 2 (Basket Materials) of WBS 1.2.2.5 (Waste Package Materials) in the Work Breakdown Structure of the Yucca Mountain Site Characterization Project.

\subsection{Scientific Investigation Plan}

The activities described in this activity plan are part of the list of activities in Scientific Investigation Plan SIP-CM-02 (Waste Package Basket Materials) (2), including change notices CN SIP-CM-02-0-1 and CN SIP-CM-02-0-2.

\subsection{Information Requirements}

One of the requirements specified in Nuclear Regulatory Commission Regulation 10CFR60 (3) pertains to the prevention of nuclear criticality in a nuclear waste repository. Nuclear waste packages for uncanistered spent nuclear fuel are being designed with basket assemblies incorporating neutron absorbers to assist in meeting this requirement. In addition, the Civilian Radioactive Waste Management Program is maintaining a specification (4) for the construction of Multi-Purpose Canisters (MPCs), and this specification includes materials requirements for neutron absorbers. Information about the corrosion behavior of potential basket materials incorporating neutron absorbers is needed to aid in selection of materials and in performance assessment for both MPCs and for uncanistered spent fuel waste packages.

\subsection{Activity Identities, Objectives and Scope}

The particular activities covered in this activity plan are designated as CM-02.2 (Scoping Experiments) and CM-02.3 (Long-Term Corrosion Testing and Properties Evaluation) in the Scientific Investigation Plan (2).

The scoping experiments will be of two types. The first type will be directed toward determining chemical environments that may be appropriate for basket materials over long time periods. The second type will consist of short-term corrosion tests of the preliminary candidate materials in bounding environments.

The long-term corrosion testing and properties evaluation will include both non-irradiated and irradiated corrosion tests of the narrowed candidate list for longer periods of time in a variety of environments. It will also include evaluation of physical, mechanical, and thermal properties of promising candidates. Measurements of these properties will be performed only as needed.

\subsection{Interfaces}

Interfaces are discussed in the Scientific Investigation Plan (2). 


\subsection{Assignments and Responsibilitics}

Richard A. Van Konynenburg is assigned as the Principal Investigator for Waste Package Basket Materials task. He reports to R. Daniel McCright, who is the Technical Area Leader for Engineered Barricr Matcrials. Paul G. Curtis is the Technical Associate assigned to this task, and he reports to Dr. Van Konynenburg.

\subsection{ACTIVITY DESCRIPTIONS}

\subsection{Sub-tasks, Technical Approaches, and Methods}

Experiments to determine chemical environments will include heating solutions of species expected to be present in vadose water with those found to be produced by radiolysis in air-water systems to determine chemical stability. Irradiation of solutions simulating vadose water may also be performed. The solutions will be submitted for chemical analysis at the beginning and at the conclusion of the experiments to observe chemical changes.

Scoping corrosion tests may include exposure of candidate materials to selected environments for short periods of time (days to weeks) with or without radiation to observe corrosion behavior, weight changes, and effects on the compositon of the corrosion medium. They may also include electrochemical polarization tests on selected materials to determine corrosion potential, corrosion current, corrosion rate at a point in time, and other corrosion characteristics.

Some long-term corrosion tests may be carried out in cooperation with the Metal Barriers Task, on selected candidates and under a variety of conditions. This is covered under a separate activity plan within the Waste Package Materials Technical Area. Other long-term tests may be conducted independently.

Properties measurements will be made in particular cases as needed, where data are not available.

When possible, standardized methods, such as those approved by ASTM or American National Standards Institute (ANSI), will be used.

Further details concerning technical approaches and methods will be described in the Scientific Notebook as the work progresses and plans become more firm.

\subsection{Materials}

Several candidates have been considered for use in waste package baskets. Currently, interest is centered principally on boron-containing stainless steels, boron carbide, and aluminum--boron carbide composites, such as Boral (a registered trademark of AAR Advanced Structures, Inc.).

\subsection{Environments}

Environments of interest are those that are likely to arise inside breached waste packages at long times in the future. Based upon current projections, these environments are likely to include air and vadose water from Yucca Mountain (including its common solutes) as well as species that are produced by irradiation of them and by their interaction with other materials in the waste packages, including breached spent fuel rods and container materials. 


\subsection{Parameters to be Measured}

Measured parameters will depend on the particular experiment, but will likely include chemical composition, temperature, pII, sample weights, electrochemical potentials and currents, radiation dose rates, and perhaps others.

The parameters measured in a particular experiment will be given in the Scientific Notebook.

\subsection{Prerequisites and Sequence of Operations}

These will depend on the particular experiment, and will be detailed in the Scientific Notebook.

\subsection{Equipment}

The equipment to be used will depend on the particular experiment, and will be listed in the Scientific Notebook. As a minimum, it is expected that the following will be used: thermometers, thermocouples and their read-out devices, $\mathrm{pH}$ meters, electronic balances, electrochemical potentiostats, and dosimeters. Other instruments will be used as needed.

\subsection{Precision and Accuracy}

Requirements for precision and accuracy will depend on the particular experiment. In scoping experiments, the purpose is to observe general trends, and high precision and accuracy are not required. In cases where property measurements are made for design or performance assessment, more attention must be paid to precision and accuracy. In general, conclusions will not be reached from scoping experiments that cannot be supported by the precision and accuracy attained in the experiments and recorded in the Scientific Notebook. In the case of property measurements for design or performance assessment, the accuracy and precision required will be based on the intended use of the data, and will be documented in the Scientific Notebook.

\subsection{Calibration and Standards}

For scoping experiments, equipment will be user-calibrated using available standards as determined by scientific judgment, since only general trends and relative behavior are the objects of study. For property measurements to be used for design or performance assessment, calibration will be performed before and after the particular experiment or series of measurements, using standards traceable to National Institute of Standards and Technology (NIST) where possible, or to other recognized standards where NIST standards are not available. For measurements that extend over time periods that are long compared to the stability of the instrument in question, calibrations will be performed at appropriate intervals. Calibrations will be documented in the Scientific Notebook.

\subsection{Sources of Uncertainty}

These will depend on the particular experiment, but are expected to result primarily from measurement uncertainty. They will be documented in the Scientific Notebook, to the degree known. 
Data will be recorded in the Scientific Notebook or in the form of separate data sheets or photomicrographs, which will be kept in looseleaf notebooks and referenced in the Scientific Notebook. Data analysis will depend on the type of data and the purpose for which it is analyzed. Analysis will be performed according to scientific or engineering judgment, and will be recorded in the Scientific Notebook.

\subsection{RECORDS}

The records that will result from these activities will be the Scientific Notebook(s) and the looseleaf notebooks referenced therein. At the conclusion of the activities, these will be turned over to the local records center as prescribed in QP 17.0.

\subsection{QUALITY ASSURANCE PROGRAM}

These activities will be conducted under the provisions of the M\&O Lawrence Livermore National Laboratory Yucca Mountain Project quality assurance procedures (5). In particular, the following procedures will apply:

$\begin{array}{ll}\text { QP 3.3 } & \text { Review of Technical Publications } \\ \text { QP 3.4 } & \text { Scientific Notebooks } \\ \text { QP 5.0 } & \text { Technical Implementing Procedures (if TIPs are needed) } \\ \text { QP 8.0 } & \text { Identification and Control of Items, Samples, and Data } \\ \text { QP 12.0 } & \text { Control of Measuring and Test Equipment (as limited in section } 2.8 \\ & \text { above) } \\ \text { QP 13.0 } & \text { Handling, Storage, and Shipping } \\ \text { QP 17.0 } & \text { Quality Assurance Records }\end{array}$

\subsection{READINESS AND TECHNICAL REVIEWS AND VERIFICATION}

No formal readiness reviews are planned. Technical reviews will be performed at the discretion of the Technical Area Leader, and will also occur as a matter of course in the normal scientific process of review of reports and papers for conferences and project meetings. No special means of verification are planned.

\subsection{HOLD POINTS AND DECISION POINTS}

No formal hold points or decision points are planned. Decisions during the course of the work will be reviewed by the Technical Area Leader and the M\&O Waste Package Materials Manager.

Data will be analyzed at the end of the Activity, at which time data will be determined whether it is Q-data or Non-Q data.

\subsection{SOFTWARE}

No specialized or complex scientific or engineering software are planned for use in these activities. 


\section{0}

TECHNICAL IMPLEMENTING PROCEDURES

No Technical Implementing Procedures are currently planned. Should they become necessary, they will be used according to QP 5.0.

\subsection{QUALIFICATIONS AND TRAINING}

Qualifications of personnel participating in these activities have been established by the Technical Area Leader under QP 2.10 and are documented in Position Descriptions on file in the Local Records Center. Quality Assurance training requirements have been established by the Technical Area Leader under QP 2.9. Environment, safety and health training requirements are established by LLNL administrative management.

\subsection{SCHEDULE}

The schedule is subject to funding. The most recent version of the Yucca Mountain Project budget and schedule will apply.

\subsection{PROCUREMENTS AND SUBCONTRACTORS}

Standard LLNL procurement practices are planned. No subcontractors are currently anticipated. If a subcontractor is used, appropriate Quality Assurance procedures will be followed.

\subsection{DELIVERABLES}

Available results from these activities will be reported to the Technical Area Leader for Performance Assessment on January 15, 1997 and July 31, 1997.

\subsection{REFERENCES}

1. U.S. Department of Energy, "Site Characterization Plan: Yucca Mountain Site, Nevada Research and Development Area, Nevada," 8 volumes, DOE/RW-0199, DOE, Washington, D.C. (1988).

2. Scientific Investigation Plan SIP-CM-02, "Waste Package Basket Materials," including changes SIP-CM-02-0-1 and SIP-CM-02-0-2, Yucca Mountain Project, Lawrence Livermore National Laboratory, Livermore, CA (1996).

3. U.S. Nuclear Regulatory Commission, "Final rule, federal regulation 10CFR Part 60, Code of Federal Regulations, Superintendent of Public Documents, U.S. Government Printing Office, Washington, D.C. (1996).

4. Civilian Radioactive Waste Management System Management and Operating Contractor, "Multi-Purpose Canister (MPC) Subsystem Design Procurement Specification," DBG000000-01717-6300-00001 06, CRWMS M\&O Document Control Center, TRW Environmental Safety Systems, Inc., Vienna, VA (June 28, 1996).

5. Lawrence Livermore National Laboratory Yucca Mountain Project, "Quality Assurance Procedures Manual," a continuously updated and controlled document. 


\section{PLANNED TRAINING}

Activity \# CM 02.2/02.3

\begin{tabular}{|c|c|c|c|}
\hline $\begin{array}{l}\text { Position for } \\
\text { Activity }\end{array}$ & $\begin{array}{l}\text { Person Filling } \\
\text { Position }\end{array}$ & $\begin{array}{l}\text { Training } \\
\text { Required }\end{array}$ & $\begin{array}{l}\text { Date for Completion } \\
\text { of Training }\end{array}$ \\
\hline \multicolumn{4}{|l|}{ EXAMPLE: } \\
\hline \multirow[t]{2}{*}{ Technician } & \multirow[t]{2}{*}{ Ron Pletcher } & QPs $6.0,17.0,13.0$ & August 1993 \\
\hline & & TIPS NF-03, NF-04 & Before Phase I \\
\hline
\end{tabular}

\begin{tabular}{|l|l|l|l|}
\hline \multirow{1}{*}{$\begin{array}{l}\text { R.A. Van } \\
\text { Konynenburg }\end{array}$} & & QPs 2.1, 2.7, 3.0, 3.3, & December 1996 \\
\cline { 3 - 4 } & & $3.4,4.0,5.0,6.0,8.0$, & \\
\hline & & $12.0,13.0,16.0$, and & \\
\hline 17.0 & & \\
\hline & & & \\
\hline Paul G. Curtis & & QPs 2.1,2.7, 3.0, 3.3, & December 1996 \\
\hline & & $3.4,4.0,5.0,6.0,8.0$, & \\
\hline & $12.0,13.0,16.0$, and & \\
\hline & & & \\
\hline & & & \\
\hline
\end{tabular}

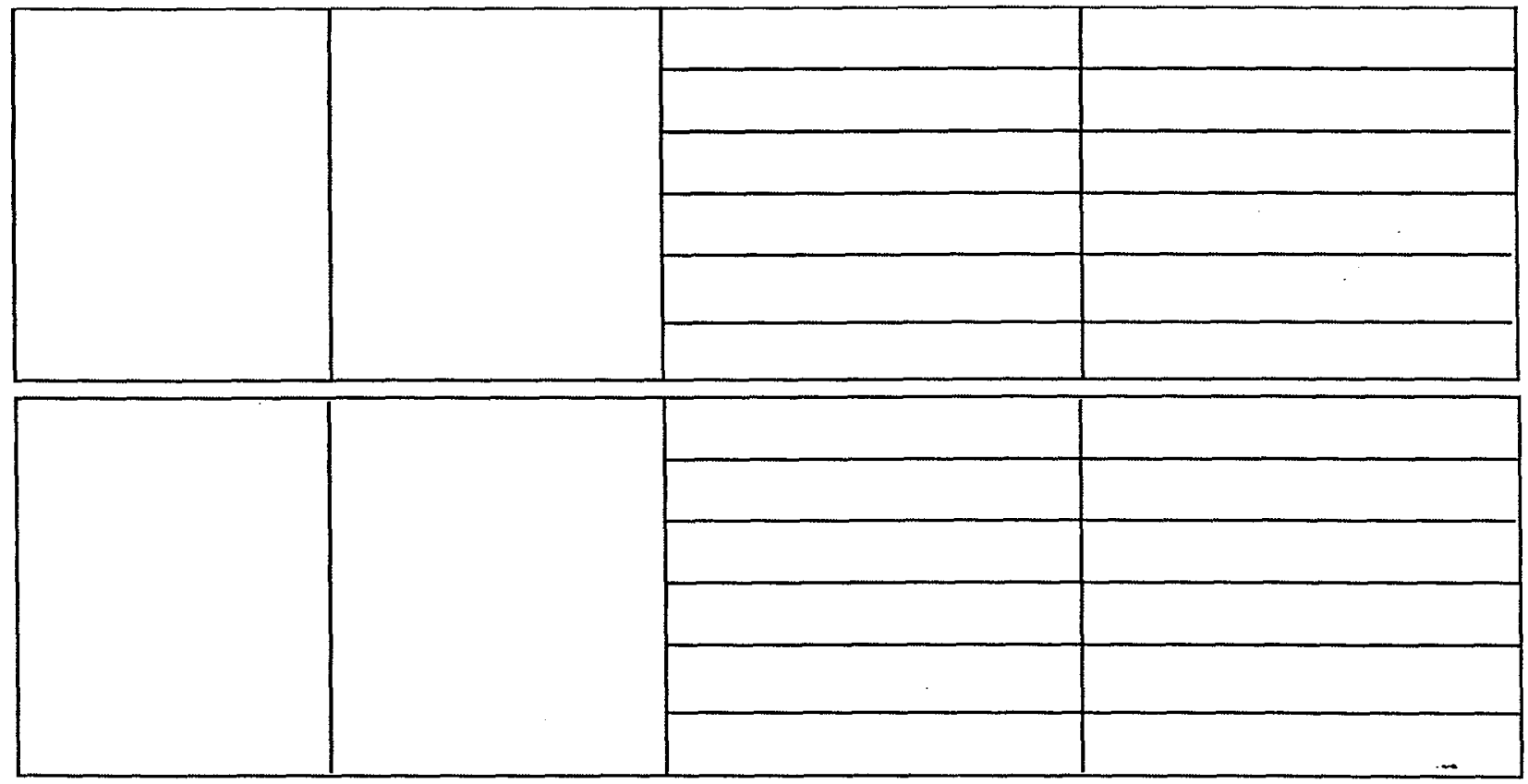


Activity \# CM 02.2/02.3

Records to be Completed for this Activity

No Yes

$\mathrm{X}$ Publications (If yes, state how many and/or subject/title, if possible, milestone?)

Conference reports and UCID reports as needed.

X Technical Implementing Procedures to be written for this activity

(If yes, state how many and/or subject/title, if possible, milestone?)

None currently planned, but may be written if found to be needed.

$X \quad$ Technical Data Input (If yes, state what type, and hold/transfer points for collection, milestone?)

X Other Records (e.g., Scientific Notebooks). Describe

Scientific Notebooks, corrosion specimens. 